\title{
Evaluation of Farmer's Woodlots: A Common Agroforestry System Used to Establish Forest Plantations
}

\author{
S.M.C.U.P. Subasinghe ${ }^{1, \#, ~ K . M . T . S . ~ J a y a r a t h n e ~}{ }^{2}$ \\ ${ }^{1}$ Centre for Forestry and Environment, Department of Forestry and Environmental \\ Science, University of Sri Jayewardenepura, Nugegoda, Co 10250, SRI LANKA \\ ${ }^{2}$ Department of Chemistry, University of Iowa, Iowa City, 52242, USA \\ ${ }^{\#}$ Corresponding Author: \\ Tele: (94) 71 4450339; E-mail: upuls@sjp.ac.lk
}

\begin{abstract}
Farmer's woodlot is a common agroforestry system used to establish forest plantations while increasing farmer's income and proper utilization of marginal lands. This study was conducted to evaluate the farmer's woodlots established in dry and intermediate zones of Sri Lanka. 17 teak plantations were selected from three districts. Three farmer's woodlots from each plantation were randomly selected for the data collection and 170 farmers were interviewed using a questionnaire survey. $d b h$ and total height were measured for the trees and soil samples were collected to determine organic carbon, nitrates, phosphorus, potassium, magnesium and calcium.

Growth of teak in farmer's woodlots was less than the average growth rates of the yield tables. Soil nutrients were present at very low levels and calcium was detected only in four plantations. Nitrate, potassium and magnesium were significantly different between the selected plantations and only nitrate was significantly correlated with teak growth.

All farmers requested to extend the present 25-year land lease agreement to earn more income from teak. Poor site quality, damage caused by wild elephants, fire, insects and pests were common so that both timber growth and the yield of seasonal crops was low. Lack of technical support was also highlighted.
\end{abstract}

Key words: Agroforestry, Farmer's woodlots, Forest soil nutrients, Teak plantations, Elephant damage

\section{Introduction}

Expansion of tropical plantation forests using tree species grown primarily as agricultural crops supplies timber for industries in considerable manner. While species and inter-species hybrids of a few genera, for example, Acacia, Eucalyptus 
and Pinus dominate worldwide, plantation forests with those of a few other species such as Araucaria, Gmelina, Larix, Paraserianthus, Popules, Pseudotsuga and Tectona are of regional importance (Evans 1992; Kanowsky 1997; Pandey and Brown 2000). In the tropics, the pioneer species such as Tectona, Pinus and Eucalyptus account $85 \%$ of all forest plantations.

About 23 Mha teak forests have been established in the Asia-Pacific region. It is being grown as plantations in at least 36 countries across three tropical regions, i.e., Tropical Asia, Tropical Africa and South America (Fisher 2000). Production of high quality wood in relatively long rotations of 50-70 years has been the usual practice ever since the world's first teak plantation was established in Kerala, India in 1842. However, shorter rotations for 20-30 years of both veneer and saw log production for relatively quick returns are also being employed in many countries (Niles et al. 2002).

Forest plantations have had a mixed history in Sri Lanka. However, it is now playing an important role in meeting the timber and fuel requirements of the nation and as an alternative timber supply to protect natural forests. At the turn of the last century, plantation establishment was aimed at replacing forests, lost through uncontrolled shifting cultivation. Those programs used Taungya system during 1950 and 1970 planting Artocarpus heterophyllus and Swietenia macrophylla in the intermediate zone and some other hardwood species such as Berrya cordifolia, Melia dubia, and Chloroxylon swietenia in the dry zone with an increasing proportion of teak (Ariyadasa 2002; Munaweera 1998).

Taungya systems were the most popular method to establish teak plantations in Sri Lanka which were conducted under agroforestry projects and later by participatory forestry projects. At present, over 35,000 ha of teak monoculture plantations are maintained by the Forest Department of Sri Lanka in the dry and intermediate zones. Apart from that, teak has been grown as mixtures with Artocarpus heterophyllus, Azadirachta indica, Eucalyptus species and Swietenia macrophylla.

Sri Lanka has a long history of participatory approaches used to rural development dating back to the 1940s. In 1980s policy makers decided to enhance the involvement of the rural community in forest management through social forestry programs. A closer perusal of such implementation programmes indicated that the forestry sector was poised to centre round the participatory management principles. Along the lines of the overall forest policy and in keeping with the necessity to get local people in managing the forest sector, the government realised the need to draw up the community participation for forest conservation and therefore several agroforestry programs were developed on the assumption that sustained forest development can only be achieved through the participation of the beneficiaries (FSMP 1995). 
Under the farmer's woodlot concept implemented by Sri Lanka Forest Department, the farmer should cultivate both forest and agricultural crops under the approval of the divisional forest officers and at least $75 \%$ of the survival of the forest crops should be maintained. Seedlings of the forest crops are supplied by the Forest Department and planting and protection should be done under their guidelines. The duration of the farmer's woodlot agreement is 25 years and it will be annually renewed up to the first five years from the date of signing the agreement. After that it will be renewed in every five years' time up to the 25 th year.

Damage by wild elephants is identified as a serious problem in the most of teak plantations established, especially in the dry zone of Sri Lanka. Teak is also vulnerable to various kinds of pests such as defoliators, skeletonisers and stem borers (Kandambi 1993). The present 25-year rotation age is believed to produce low timber yields than the expected values of the Forest Department provisional yield tables (Silva and Amarasekara 2007).

\section{Materials and Methods}

Farmer's woodlots were established in Sri Lanka under agroforestry programs in Anuradhapura, Polonnaruwa, Monaragala and Badulla districts of the dry zone and Kurunegala district of the intermediate zone. Most of the plantations were between 8 to 13 years old at the time of data collection for this study. In another 10 to 15 years' time, these plantations will be suitable for final felling to extract timber for the commercial use.

17 teak plantations aged between 8 to 13 years established under farmer's woodlots programs were selected for the present study (Table 1). Each plantation contained many farmer woodlots varying from 1 to 2 ha. Anuradhapura and Polonnaruwa districts were selected to represent the dry zone and Kurunegala district was selected to represent the intermediate zone. Those three districts contain $24.1 \%$ of the total land area of the country. Anuradhapura, Tambuttegama and Kekirawa were the selected forest ranges from Anuradhapura district. In Polonnaruwa and Kurunegala districts farmer's woodlots were present only in Habarana and Galgamuwa forest ranges and therefore those two ranges were selected to represent the above two districts (Table 1).

Three farmer woodlots were randomly selected from each plantation for the data collection and three samples of 0.02 ha were used for the tree measurements from each woodlot. Breast height diameter (dbh) and total height of teak were measured from samples. Soil samples were collected up to $30 \mathrm{~cm}$ at the middle of each sampling point to determine total nitrates, phosphorus, potassium, calcium, magnesium and organic carbon. 
A questionnaire survey was employed to gather information on farmers' views on the current forestry program. Ten farmers were selected from each plantation for this survey and thereby 170 famers were interviewed. Information on agricultural crops intercropped with teak, soil fertility and erosion, adequacy of the government support, growth of timber, problems faced etc. were obtained from the questionnaire. In addition, the suggestions of the farmers to improve this agroforestry program were also obtained.

Due to the varying ages of the selected plantations for the present study, it was not possible to test the correlations between the tree growth and soil properties. In order to eliminate that problem, a simple growth index was developed by dividing the average tree height by the plantation age (Growth index $=$ total tree height/plantation age Eq. (1).

Growth index $=$ total tree height/plantation age

Eq. ( 1 )

\section{Results}

\section{Growth of teak in the farmer's woodlots}

Both dbh (Figure 1) and height (Figure 2) growth varied between different plantations and a clear increase of those two variables with the age was not observed. The highest growth index (1.68) was observed for the 8-year-old plantation of Kekirawa range and the lowest growth index (0.67) was recorded in Anuradhapura range which proved the variation of growth even within the districts. Both ranges belong to Anuradhapura district. When compared to the teak yield tables published by Sri Lanka Forest Department, growth of teak in farmer's woodlots was below the average rates. 


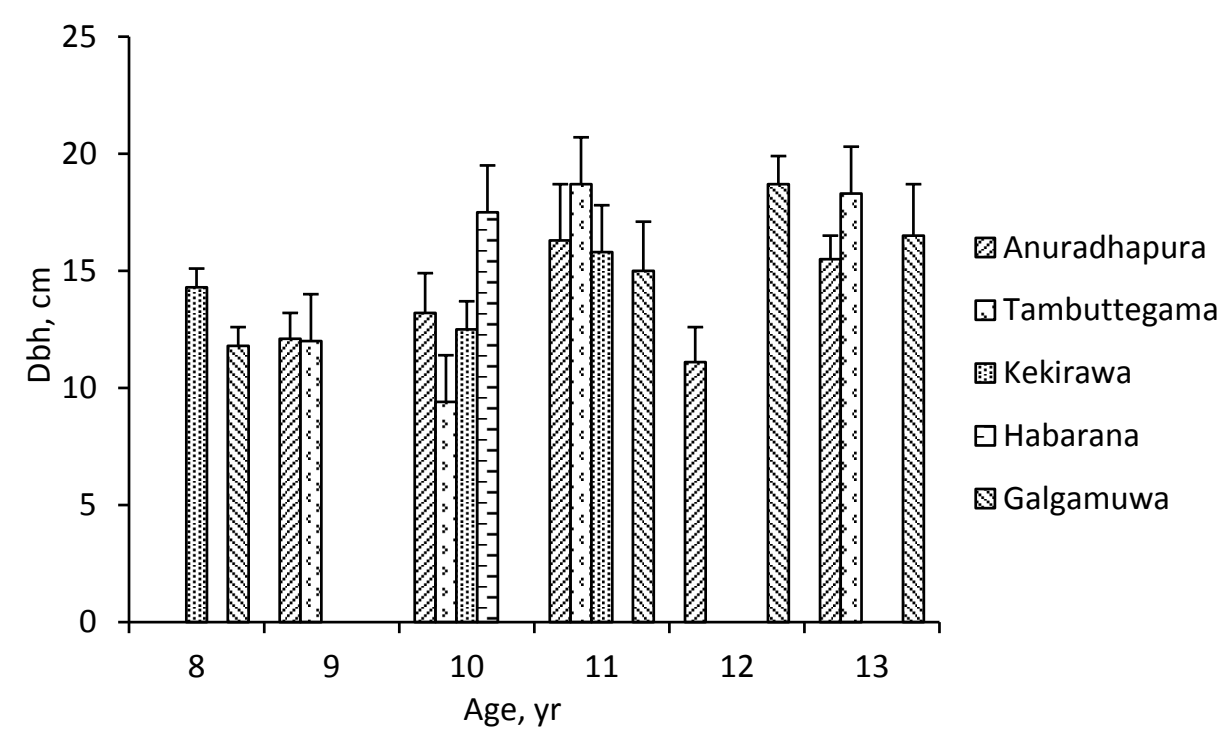

Figure 1: Average dbh values of the selected plantations of each forest range (土SE)

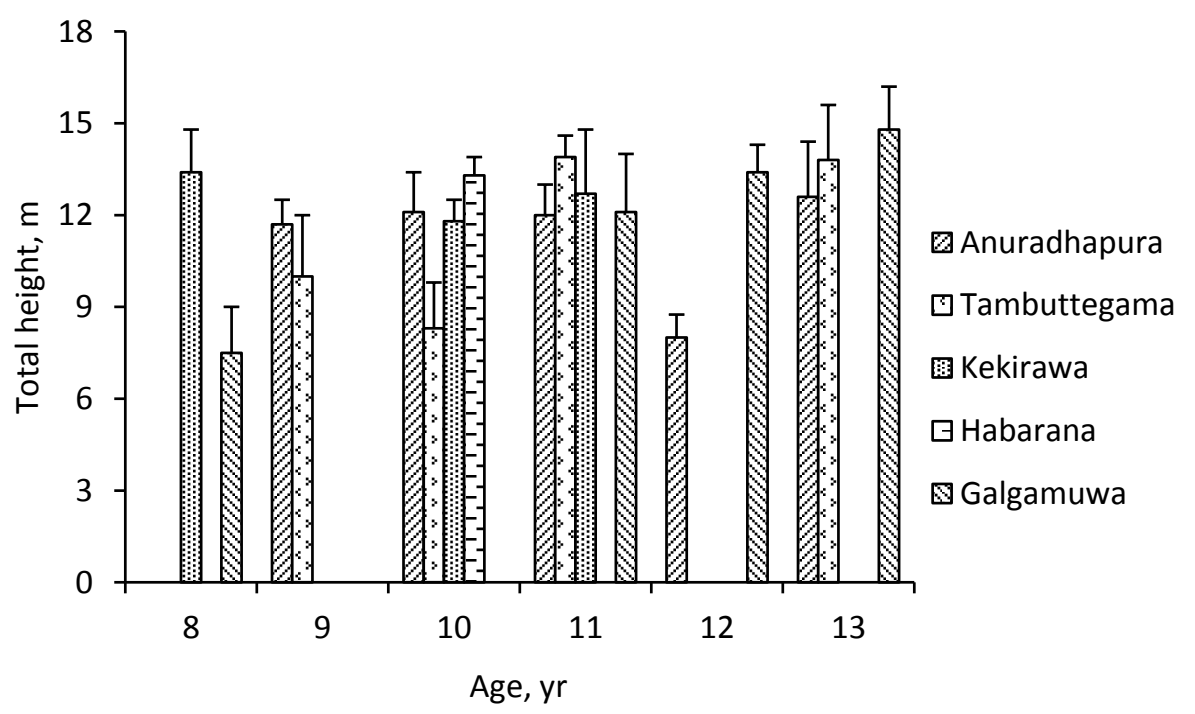

Figure 2: Average height values of the selected plantations of each forest range $( \pm$ SE) 


\section{Soil nutrient variations}

Organic carbon contents indicated low values ranging from $1.23 \%$ to $4.91 \%$ for all plantations (Table 1). However, it was below $3.0 \%$ for 14 plantations which could be due to the occurrence of frequent fires in most of the plantations.

Soil nitrate contents were less than 4.5 ppm for all plantations. Plantation 15 (9.33 ppm), 7 (7.47 ppm) and $17(5.84 \mathrm{ppm})$ respectively (Table 1) had the significantly highest nitrate contents $(\mathrm{F}=34.02, \mathrm{p}=0.000)$ than the rest of the plantations. The lowest values were recorded from plantation $3(1.98 \mathrm{ppm})$ and $10(2.133 \mathrm{pm})$ respectively.

Phosphorous contents of soils did not significantly vary between the 17 plantations $(\mathrm{F}=1.76, \mathrm{p}=0.084)$. Those values ranged from 56.0 to $168.7 \mathrm{ppm}$. However, only three plantations had the soil phosphorous values above 150 ppm (Table 1).

Soil potassium contents had significant differences $(\mathrm{F}=39.41, \mathrm{p}=0.000)$ Plantation 10 and 15 (Table 1 ) respectively had the significantly highest potassium contents $(8.38$ and $8.25 \mathrm{ppm}$ ) while plantations 4,3 and 1 had the lowest potassium contents (1.99, 2.12 and 2.83 ppm respectively) in the soil.

Magnesium contents also varied in significant manner in the plantation soils $(\mathrm{F}=23.38, \mathrm{p}=0.000)$. The highest soil magnesium contents varying from 7.82 to 8.33 ppm were observed in all plantations of Galgamuwa range (Table 1) which was the only range located in the intermediate zone where farmer's woodlots were present. All the other selected plantations were located in the dry zone and the magnesium values for those plantations were less than $5.7 \mathrm{ppm}$.

Soil calcium, considered as an essential nutrient for growth of teak was detected only in four plantations. Among them, the highest value $(0.31 \mathrm{ppm})$ was recorded from the only plantation selected from Habarana range of Polonnaruwa district (Table 1). Two of the rest of three plantations, viz. Plantation 14 and 16, were located in Kurunegala district and the other, viz. Plantation 3, was located in Anuradhapura range. 
Table 1: Plantations used and summary of the data

\begin{tabular}{|c|c|c|c|c|c|c|c|c|c|c|}
\hline District & Range & No & $\begin{array}{l}\text { Age, } \\
\text { yr }\end{array}$ & $\begin{array}{l}\text { Organic } \\
\mathrm{C} \%\end{array}$ & $\begin{array}{l}\text { Nitrate, } \\
\text { ppm }\end{array}$ & $\mathrm{P}, \mathrm{ppm}$ & $\mathrm{K}, \mathrm{ppm}$ & $\begin{array}{l}\mathrm{Ca}, \\
\mathrm{ppm}\end{array}$ & $\begin{array}{l}\mathrm{Mg} \\
\mathrm{ppm}\end{array}$ & Observed problems \\
\hline Anuradhapura & Anuradhapura & 1 & 13 & 2.79 & $4.07(0.29)$ & $56.0(7.65)$ & $2.83(0.39)$ & ND & $4.42(0.51)$ & Recent fire \\
\hline Anuradhapura & Anuradhapura & 2 & 11 & 2.95 & $4.09(0.93)$ & $127.7(32.2)$ & $3.68(0.53)$ & ND & $4.32(0.38)$ & Recent fire \\
\hline Anuradhapura & Anuradhapura & 3 & 12 & 3.63 & $1.98(0.71)$ & $74.7(18.0)$ & $2.12(0.08)$ & 0.02 & $4.81(0.44)$ & Gravel, High erosion \\
\hline Anuradhapura & Anuradhapura & 4 & 9 & 2.63 & $3.70(0.24)$ & $150.3(7.6)$ & $1.95(0.35)$ & ND & $4.72(0.26)$ & Recent fire \\
\hline Anuradhapura & Anuradhapura & 5 & 10 & 2.95 & $4.02(0.62)$ & $154.7(26.8)$ & $3.24(0.61)$ & ND & $4.92(0.29)$ & Recent fire, Elephant damage \\
\hline Anuradhapura & Kekirawa & 6 & 10 & 2.99 & $4.67(0.64)$ & $105.3(35.7)$ & $5.22(0.59)$ & ND & $4.72(0.57)$ & Recent fire \\
\hline Anuradhapura & Kekirawa & 7 & 8 & 1.23 & $7.47(1.43)$ & $94.7(52.2)$ & $3.97(0.47)$ & ND & $3.40(0.30)$ & Recent fire \\
\hline Anuradhapura & Kekirawa & 8 & 11 & 1.99 & $3.38(0.31)$ & $82.0(47.8)$ & $4.12(0.52)$ & ND & $4.13(0.42)$ & Recent fire \\
\hline Anuradhapura & Tambuttegama & 9 & 13 & 2.08 & $2.93(0.41)$ & $135.7(2.1)$ & $5.04(0.44)$ & ND & $5.63(0.75)$ & \\
\hline Anuradhapura & Tambuttegama & 10 & 10 & 2.63 & $2.13(0.10)$ & $138.0(10.2)$ & $8.38(1.33)$ & ND & $5.49(0.64)$ & Recent fire \\
\hline Anuradhapura & Tambuttegama & 11 & 9 & 2.26 & $4.43(0.30)$ & $105.7(14.0)$ & $5.77(0.29)$ & ND & $5.47(0.53)$ & Recent fire \\
\hline Anuradhapura & Tambuttegama & 12 & 11 & 3.43 & $3.98(0.49)$ & $119.0(28.2)$ & $5.99(0.72)$ & ND & $5.43(0.61)$ & \\
\hline Kurunegala & Galgamuwa & 13 & 8 & 2.65 & $2.74(0.01)$ & $168.7(44.4)$ & $5.62(0.38)$ & ND & $8.28(0.75)$ & Recent fire, Elephant damage \\
\hline Kurunegala & Galgamuwa & 14 & 13 & 2.79 & $3.56(0.13)$ & $143.5(38.9)$ & $3.68(0.41)$ & 0.05 & $8.33(0.56)$ & $*$ \\
\hline Kurunegala & Galgamuwa & 15 & 11 & 4.91 & $9.33(0.48)$ & $142.0(26.9)$ & $8.25(0.97)$ & ND & $7.82(0.81)$ & \\
\hline Kurunegala & Galgamuwa & 16 & 12 & 2.95 & $3.16(0.24)$ & $139.7(26.1)$ & $5.59(0.65)$ & 0.02 & $8.23(0.73)$ & $*$ \\
\hline Polonnaruwa & Habarana & 17 & 10 & 2.28 & $5.84(0.48)$ & $116.3(38.2)$ & $4.32(0.28)$ & 0.31 & $4.56(0.61)$ & Naturalised \\
\hline
\end{tabular}

* Azadirachta indica (neem) were planted in alternative rows.

$\mathrm{ND}=$ not detected . 


\section{Correlation between growth and soil nutrients}

Soil nitrate was the only significantly correlated soil nutrient $(r=0.897, p=0.000)$ with the growth index calculated for teak growing in the study sites. Rest of the soil nutrients, viz. organic carbon $(\mathrm{r}=0.445, \mathrm{p}=0.073)$, phosphorus $(\mathrm{r}=0.411, \mathrm{p}=0.102)$, potassium $(\mathrm{r}=-0.103, \mathrm{p}=0.694)$ and magnesium $(\mathrm{r}=0.436, \mathrm{p}=0.157)$ were nonsignificant.

\section{Results of the questionnaire survey}

Due to the distinctive two rain period and dry climate in between, farmers had only two seasons per year for cultivating the agricultural crops in their woodlots. Maize, sesame, chilli and finger-millet were the main seasonal crops used within the first five years from the establishment of the farmers' woodlot program. There was no consistency of the selection of the crops for each season. Perennial agricultural crops were not selected because of the prevailing dry periods for over 7-8 months. Due to the canopy closure, only the first five years were available for the farmers for cultivating agricultural crops and their income decreased after that period was over.

All respondents indicated that the 25 -year lease period was not adequate to obtain a considerable income by selling timber because of slow growth of teak than the expected values. Therefore, they requested to increase the lease period for 30 to 50 years. In addition to that, $98 \%$ of the farmers interviewed needed to continue the farmer woodlot program for the second cycle. Rest of $2 \%$ were not happy about the generated income and therefore expected to migrate to the cities seeking for better employment opportunities.

Frequent fire was one of the main problems faced by the farmers when managing their woodlots. Sometimes they deliberately created ground fire to eradicate the caterpillars crawled towards their homesteads which originated in very large numbers in the teak plantations after heavy rain periods. Once started, fire spread rapidly due to the thick dry leaf layer on the ground and prevailing high winds, severely damaging both teak and agricultural crops.

The most prevalent insect attacks for the teak plantations were the skeletoniser, defoliator and stem borer. Stem borer attack was common in the early ages of teak plants which may disappear with the maturity. However, skeletoniser attack was more frequent after the rain periods in the study areas. Although teak does not die due to the skeletoniser attack, its photosynthesis ability is drastically reduced. Application of insecticides was not possible due to the height of the trees and lack of adequate finance to afford the chemicals and labour. 
Lack of water for the irrigation activities was a constraint, especially for their shortterm cash crops. $20 \%$ of the farmers had their own agro-wells or agro-wells used on shared basis. Water collected manually or using fuel-driven pumps from those wells were used for the irrigation purposes for the agricultural crops. Others used only the rain water and therefore there was a high risk in drying out their crops in the dry periods. However, none of the respondents irrigated teak plants even at the early stages.

$18 \%$ of the respondents complained about wild elephant damage in their plantations which were common in Anuradhapura range, Kekirawa range and Galgamuwa range. However, elephant damages were not recorded when the plantations were naturalised with a thick undergrowth as evidenced in some plantations of Habarana range or when the plantations were established with a considerable amounts of neem (Azadirachta indica) as recorded in Galgamuwa beat of Galgamuwa range.

$62 \%$ of respondents indicated that they required more technical support from the forest officers, especially in the periods of pruning of teak. In addition to that, there were no specific management plans prepared for farmer's woodlot management. Teak yield tables are available for three growth classes managed as even-aged monocultures. However, the spacing and management prescriptions are different in farmer's woodlots and therefore it is necessary to have separate plans.

\section{Discussion}

It was clear that the growth of teak in farmer's woodlots were lower than the expectations. Technical advices were not adequately provided to the farmers on cultivating their seasonal crops. Tree growth is usually correlated with the soil properties and management techniques. Growth dynamics of plant populations are determined not only by species-specific properties, but also by biotic and abiotic factors such as neighbourhood, competition and environmental heterogeneity (Kubota and Hara 1996; Rouifed et al. 2010). Climate, physiography and soil comprise the abiotic factors that exert a significant influence on population development. Climatic and physiographic factors can be considered constant on similar geological regions and then soil properties become the major factor of the physical environment that has an appreciable bearing on the tree growth (Kubota and Hara 1996). This was evidenced in the present study because the soil nutrient levels, especially organic carbon and phosphorous, were in very low amounts. Calcium, an essential nutrient for a better growth of teak was detected only in four out of 17 plantations further proving the poor conditions of soil. Correlations tests revealed all tested nutrients were not significant for the growth of teak other than nitrate contents indicating large variations of growth. Therefore, enhancement of the soil fertility 
should be considered to increase the productivity for both timber and agricultural species at least from the next cycle.

Undisturbed plantations showed higher growths in the study sites than the sites where disturbances occurred due to fire, insects and elephant damages. Ten out of 17 plantations were frequently subjected to heavy fires. Ground fires significantly reduce the carbon sequestration in forests (Tilman et al. 2000). According to Reich et al. (2001), above ground net primary productivity of forests is inversely correlated with the frequencies of surface fires. Calcium reserves of the soil are severely affected by forest fires (Hase and Foelster 1983). Moreover, the avoidance of mechanical site clearings and the removal of soil cover during the site preparation and establishment of teak plantations could reduce nutrients losses caused by erosion and leaching.

If controlled burning is implemented, fires of low intensity may increase the quantities of nitrogen, phosphorus, potassium and calcium in soil (Carter and Foster, 2004). However, Radke et al. (2001) stated that the use of controlled fire to meet the needs of forest managers is increasingly in collision with the air pollution and climate change issues. The plantations where the calcium was not detected in the present study were undergone frequent fire hazards. According to the farmers, most of those fires were deliberately set by them to eradicate weeds and caterpillars. Burning of litter may reduce the soil moisture. Under undisturbed conditions, annual litter decomposition and atmospheric nitrogen input can supply more than $70 \%$ of the nitrogen requirements of the stand. However, regular burning reduces this amount to less than 15\% (Drechsel and Zech 1994).

Human-elephant conflict is frequently reported form the study areas which could be due to the habitat fragmentation of the animals. Erections of electric fences of certain areas are in progress, but still the issue is prevalent. Since elephants do not like to enter the lands with thorny vegetation, growing of lime along the borders can be considered as prevention. They also do not prefer Azadirachta indica and therefore it can be selected instead of teak from the next cycle to minimise the damage.

Provision of adequate technical support is essential in participatory forestry approaches implemented with the local community. As farmers mentioned, the support is not adequate for the timber management, the number of relevant officers should be increased by the Sri Lanka Forest Department. In addition, better incomes can be generated if the agriculture officers are also join such programs for educating the farmers on cultivation of short-term crops matching with the climate and soil conditions. 


\section{Conclusions}

Results of this study indicated that the lands which were allocated to establish farmer's woodlots were marginal in quality. Most of those lands had undergone frequent fires and erosion for a long period of time and therefore suffered from nutrient loss. Therefore, it is essential to consider soil enhancement activities to improve the productive. Teak should be changed to Azadirachta indica from the next management cycle to minimise the damage from the wild elephants. In addition, proper technical support should be provided to the farmers while considering increasing the land lease period in accordance with the growth of teak.

\section{References}

Ariyadasa, K.P. (2002). Assessment of tree resources in home gardens of Sri Lanka, FAO Report, Bangkok, Thailand.

Carter, C.C. and Foster, C.D. (2004). Prescribed burning and productivity in southern pine forests: a review, Forest Ecology and Management, 191: 93-109.

Drechsel. P. and Zech, W. (1994). Evaluation of teak (Tectona grandis L.f.) mineral nutrition and effect of nutrition and site quality on teak growth in West Africa, Forest Ecology and Management, 70: 121-133.

Evans, J. (1992). Plantation forestry in the tropics. Oxford University, Clarenden Press, UK.

Fisher, R.J. (2000). Decentralization and devolution of forest management: A conceptual overview. In: Decentralization and devolution of forest management in Asia and Pacific, RECOFT Report No 18 (T. Enters, Durst, P.B. and Victor, M. Eds.), Bangkok, Thailand.

FSMP. (1995). Forestry Sector Master Plan. Forest Department, Sri Lanka.

Hase, H. and Foelster, H. (1983). Impacts of plantation forestry with teak (Tectona grandis) on the nutrient status of young alluvial soils in west Venezuela, Forest Ecology and Management, 6: 33-57.

Kandambi, K. (1993). Silviculture and management of teak. Natraj Publishers, India.

Kanowsky, P.J. (1997). Afforestation and plantation forestry. Arrow Discovery Service, Australia.

Kubota, Y. and Hara, T. (1996). Allometry and competition between saplings of Picea jezoensis and Abies sachalinensis in a sub-boreal coniferous forest, northern Japan, Annals of Botany, 77: 529-537. 
Munaweera, D.P. (1998). Growth and yield simulation models for management evenaged teak plantations. M.Phil. Dissertation, University of Sri Jayewardenepura, Sri Lanka.

Larson, A. (2002). Natural resources and decentralising in Nicaragua: are local governments up to the job? World Development, 31(1): 17-31.

Niles, J.O., Brown, S., Pretty, J., Ball, A.S. and Fay, J. (2002). Potential carbon mitigation and income in developing countries from changes in use and management of agricultural and forest lands, Philosophical Transactions of the Royal Society, 360: 1621-1639.

Pandey, D. and Brown, C. (2000). Teak: a global overview, Unasylva, 51: 3-13.

Radke, L.F., Ward, D.E. and Riggan, P.J. (2001). A prescription for controlling the air pollution resulting from the use of prescribed biomass fire, International Journal of Wildland Fire, 10(2): 103-111.

Reich, P.B., Peterson, D.W., Weding, D.A. and Wrage, K. (2001). Fire and vegetation effect on productivity and $\mathrm{N}$ cycling across a forest-grassland continuum, Ecology, 82: 1703-1719.

Rouifed, S., Handa, I.T., David, J. and Hattenschwiler, S. (2010). The importance of biotic factors in predicting global change effects on decomposition of temperate forest leaf litter, Global Change Ecology, 163: 247-256.

Silva, P.R. and Amarasekara, H.S. (2007). Assessment of sustainable forest management practices in farmer's woodlot teak plantations in selected districts of Sri Lanka. In: Proceeding of 12th International Forestry and Environment Symposium, University of Sri Jayewardenepura, Nugegoda, Sri Lanka

Tilman, D., Knops, J., Reich, P., Peterson, D., Phillips, H., Menton, M., Patel, A. and Vos, E. (2000). Fire suppression and ecosystem carbon storage, Ecology, 81: 2680-2685. 